\title{
Permanent Atrial Standstill: The Clinical Spectrum
}

\author{
JAMES WOOLLISCROFT, MD \\ NAIP TUNA, MD, PhD, FACC \\ Ann Arbor, Michigan and \\ Minneapolis, Minnesota
}

From the Department of Internal Medicine, Division of Primary Care/Community Medicine, The University of Michigan, Ann Arbor, Michigan and the Department of Internal Medicine, Section of Cardiology, University of Minnesota, Minneapolis, Minnesota. Manuscript received June 16, 1981, revised manuscript received December 2, 1981, accepted December 10, 1981.

Address for reprints: James Woolliscroft, MD, Primary Care/Community Medicine, D5101 South Ambulatory Care Building. The University of Michigan Medical School, Ann Arbor, Michigan 48109 .

\begin{abstract}
Permanent atrial standstill appears to be an arrhythmia that develops because of extensive myocardial disruption. It has been noted in three clinical settings: in patients with long-standing cardiac disease, in patients with neuromuscular disease and in otherwise healthy people who present with vertigo, syncope or stroke. A patient with this arrhythmia and limbgirdle muscular dystrophy is presented.
\end{abstract}

Permanent atrial standstill is an infrequently recognized arrhythmia that was initially well described in 1946 by Chavez et al. ${ }^{1}$ The current diagnostic criteria include: (1) absence of $\mathrm{P}$ waves in surface and intracavitary electrocardiograms; (2) absence of A waves in jugular venous pulse and right atrial pressure tracings; (3) supraventricular type QRS complex; (4) immobility of atria on fluoroscopy; and (5) inability to stimulate the atria electrically. ${ }^{2}$

Permanent atrial standstill has been diagnosed in three clinical settings: in patients with long-standing progressive cardiac disease, in patients with neuromuscular disease and in patients with absent $P$ waves in an electrocardiogram taken during evaluation of vertigo, syncope or stroke. Recognition of the settings in which permanent atrial standstill occurs may facilitate the diagnosis and the initiation of appropriate therapy. An illustrative case is presented:

\section{Case History}

A 34 year old white man was referred to the University of Minnesota Hospitals for evaluation of bradycardia and an abnormal electrocardiogram. At age 14, he was noted to have cardiomegaly during an evaluation for a "functional" murmur. He was hospitalized for left anterior chest pain at age 21 years. Electrocardiograms showed what was interpreted as "a nodal rhythm with a rate of 38 to $52 / \mathrm{min}$." At age 29 , he experienced the sudden onset of slurred speech, dizziness and numbness in his left arm that resolved within 20 minutes. He was examined in an emergency room where the electrocardiogram showed absent $P$ waves and a heart rate of 42 beats $/ \mathrm{min}$. He noted progressive weakness and wasting of his upper arms and pelvic musculature beginning in his late $20 \mathrm{~s}$.

Physical examination showed a slender man with marked upper arm and shoulder girdle atrophy. His blood pressure was $134 / 62 \mathrm{~mm} \mathrm{Hg}$ with no orthostatic decrease; the pulse was $38 / \mathrm{min}$ and regular. The point of maximal impulse was in the fifth intercostal space $4 \mathrm{~cm}$ lateral to the mid clavicular line. Jugular venous A waves were absent. A grade $2 / 6$ systolic ejection murmur was hest heard at the left sternal border.

All laboratory data were normal except serum creatine kinase (CK), which was elevated in the range of 149 to $166 \mathrm{U} /$ liter (normal 0 to 65). The CK-MB isoenzyme ranged from 2 to $4 \mathrm{U} /$ liters (normal 0 to 2.0 ). The electrocardiogram showed bradycardia and absence of $\mathrm{P}$ waves (Fig. 1). An echocardiogram showed left atrial and ventricular enlargement. The aortic, mitral and tricuspid valves were normal. No evidence of "atrial kick" was present on recordings of the mitral valve indicating absence of left atrial mechanical activity (Fig. 2). A chest X-ray 
film showed cardiomegaly. Fluoroscopy showed a large right atrium and noncontractile atria.

A treadmill exercise test was terminated because of fatigue in stage III of the Bruce protocol at 6 minutes, 5 seconds. The heart rate rapidly increased to 120 beats/min during exercise. The QRS configuration did not change and no $P$ waves were evident.

Atrial electrical activity measured with intracardiac electrodes was absent. Atrial pacing was attempted at multiple sites at up to $15 \mathrm{~mA}$ with no response. The ventricles were easily paced with $0.5 \mathrm{~mA}$. There was no evidence of retrograde atrial activity during ventricular pacing. Resting hemodynamic data, at a heart rate of 40 beats $/ \mathrm{min}$, showed a slight increase in left and right side filling pressures and a dip and plateau configuration in the right ventricular pressure tracing that was characteristic of a restrictive cardiomyopathy. Ventricular pacing produced an increase in cardiac output (Table I).
The clinical features, muscle biopsy, electromyogram and nerve conduction studies were consistent with the diagnosis of limb-girdle muscular dystrophy. A right ventricular demand pacemaker was inserted and treatment with oral anticoagulant agents was begun. Muscular weakness has progressed, but no other problems have developed in 3 years of follow-up study.

Family history: Evaluation of the patient's son showed a normal electrocardiogram and no muscular abnormalities. The patient's brother had a history of bradycardia and a murmur noted at age 14 years. At age 23 years, cardiac catheterization showed multichamber cardiac enlargement without valve disease. The electrocardiogram showed absent $P$ waves and a supraventricular type QRS complex at a heart rate of 38 beats $/ \mathrm{min}$. He died suddenly at age 32 years. The heart weighed $500 \mathrm{~g}$ at autopsy. Autolysis prevented microscopic examination. There was no history of muscle weakness.
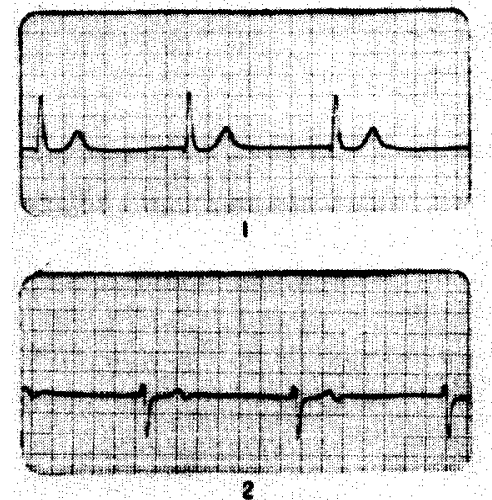

2

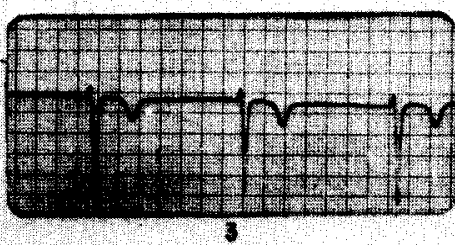

)

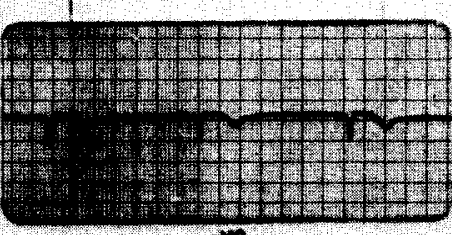

and

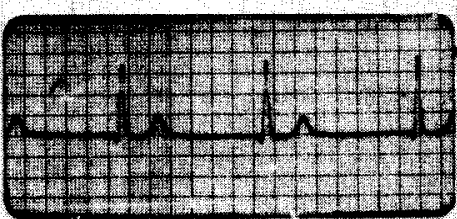

a

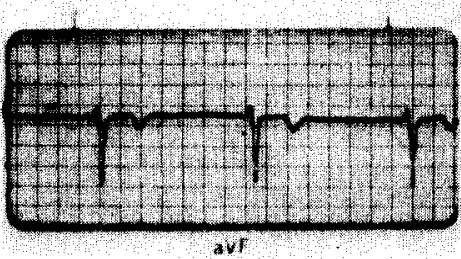

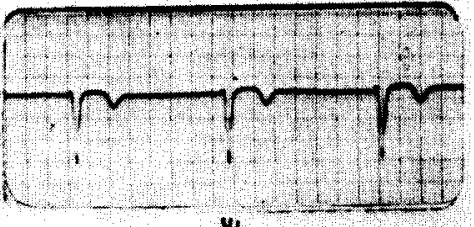

Ni:
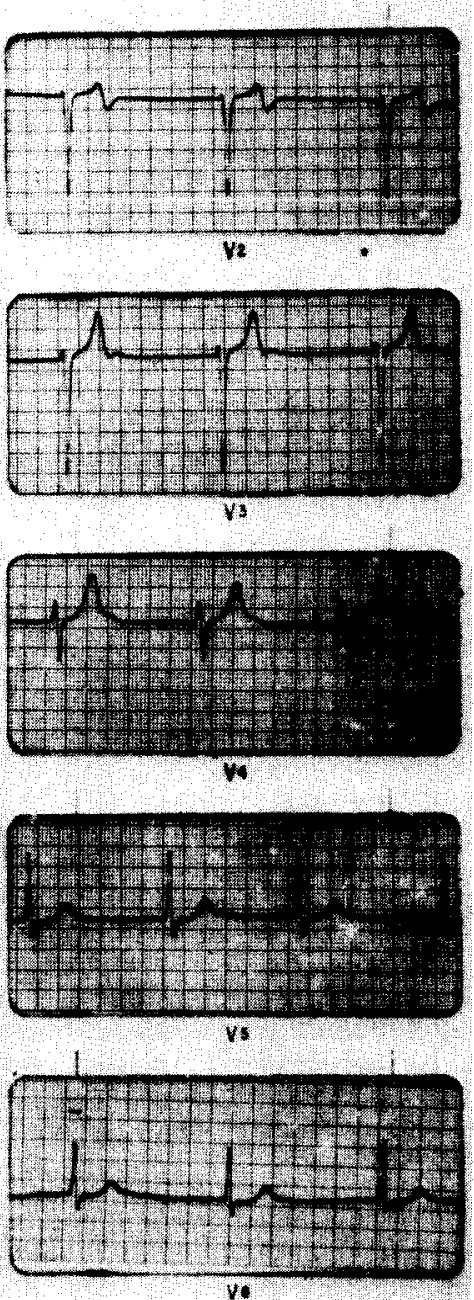

FIGURE 1. Surface electrocardiogram at time of presentation. $R-R$ interval is constant. $P$ waves are absent throughout. 


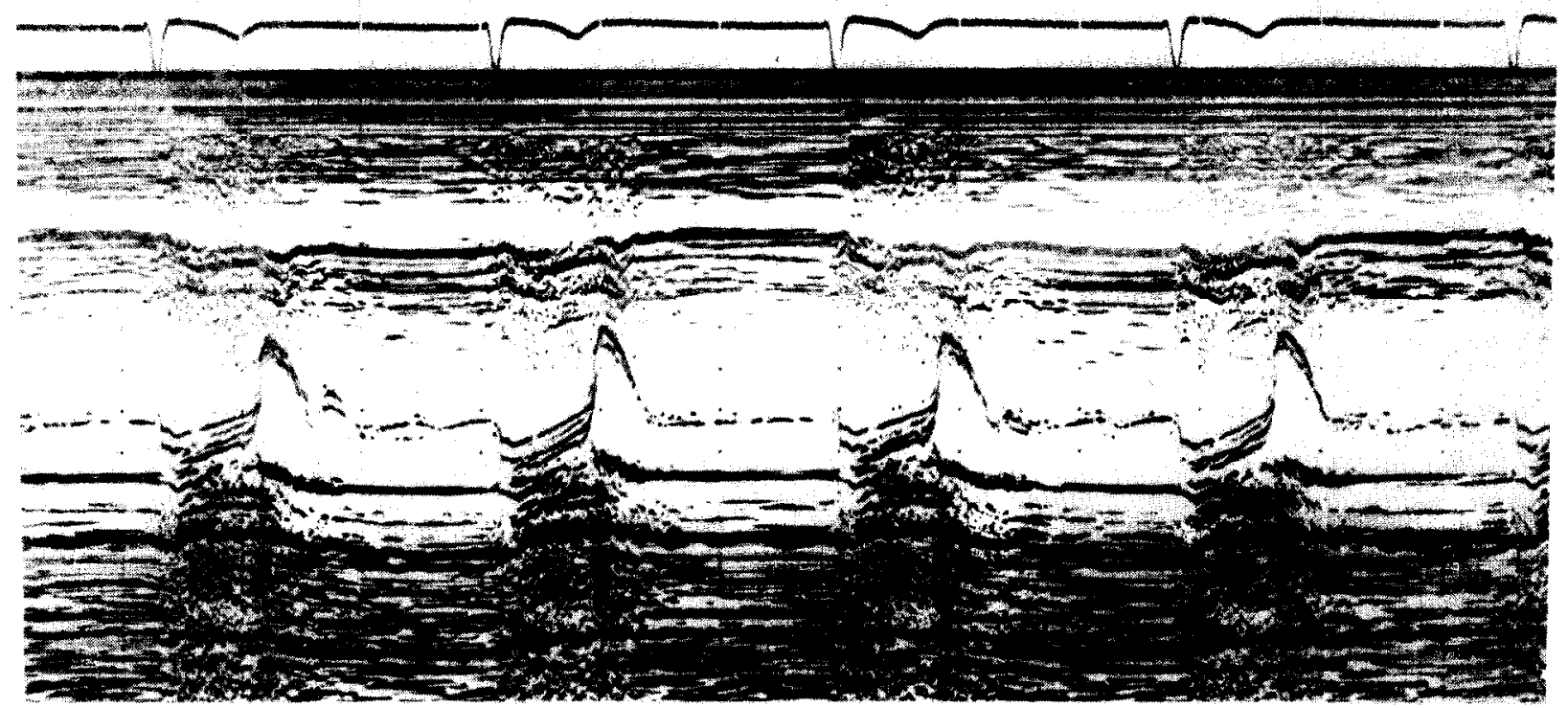

FIGURE 2. Echocardiogram of mitral valve. End-diastolic "atrial kick" or A wave of anterior mitral leaflet is absent.

\section{Discussion}

We have identified 55 patients with well-documented permanent atrial standstill. They fall into three clinical groups (Table II).

Patients with long-standing cardiac disease: In the first group permanent atrial standstill develops progressively as a sequela to long-standing cardiac disease with a prior history of supraventricular arrhythmias. There appears to be a continuum of myocardial disruption and fibrosis that may result in permanent atrial standstill. The first step is temporary atrial standstill that spontaneously converts to normal sinus rhythm. Patients with this condition respond to atrial pacing during standstill. ${ }^{41}$ Further impairment is evidenced by absent atrial activity in surface electrocardiograms, fluoroscopy and pressure tracings. However, intracardiac electrocardiograms show low voltage atrial potential and a response to atrial pacing at high voltage remains. ${ }^{3}$ More limited right atrial activity localized to the septum and responsive to atrial pacing only in that area ${ }^{4}$ progresses to similar findings of low voltage atrial activity recorded in the tricuspid area $^{58}$ or high lateral atrial wall, ${ }^{9}$ but without response to atrial pacing.

Perhaps the final progression to permanent atrial standstill is documented in a patient with two surface electrocardiographic patterns; neither showed atrial electrical activity..$^{10}$ Intracavitary electrocardiograms showed no electrical activity in the right atrium and coronary sinus during the first pattern. Atrial pacing was unsuccessful. Intracavitary electrocardiograms during the second pattern showed regular electrical activity in the lower portion of the right atrium and coronary sinus. Epicardial mapping showed low amplitude atrial activity in the tricuspid area, with outward propagation from a center near the tricuspid area. $\mathrm{Bi}$ -

TABLE I

Hemodynamic and Ventricular Pacing Study

\begin{tabular}{|c|c|c|c|c|}
\hline & \multirow{2}{*}{$\begin{array}{l}\text { Intrinsic } \\
\text { Rhythm }\end{array}$} & \multicolumn{3}{|c|}{ Pacing } \\
\hline & & $60 / \mathrm{min}$ & $80 / \mathrm{min}$ & $100 / \mathrm{min}$ \\
\hline $\begin{array}{l}\text { Wedge pressure }(\mathrm{mm} \mathrm{Hg}) \\
\text { Aortic pressure (mm } \mathrm{Hg} \text { ) } \\
\text { Pulmonary arteriolar pressure (mm Hg) } \\
\text { Right atrial pressure } \\
\text { Cardiac output (liters } / \mathrm{min} \text { ) } \\
\text { Cardiac index (liters/min per } \mathrm{m}^{2} \text { ) } \\
\text { Heart rate (beats } / \mathrm{min} \text { ) } \\
\text { Stroke volume (ml) } \\
\text { Systemic resistance (dynes } / \mathrm{cm}^{-5} \text { ) } \\
\text { Total pulmonary resistance (dynes } / \mathrm{cm}^{-5} \text { ) } \\
\text { Puimonary arteriolar resistance (dynes } / \mathrm{cm}^{-5} \text { ) }\end{array}$ & $\begin{array}{l}(18) \\
151 / 81(109) \\
40 / 18(25) \\
(11) \\
5.5 \\
3.1 \\
40 \\
138 \\
1,585 \\
364 \\
102\end{array}$ & $\begin{array}{l}(16) \\
151 / 87(120) \\
39 / 16(27) \\
-7.8 \\
4.5 \\
60 \\
130 \\
1,231 \\
277 \\
113\end{array}$ & $\begin{array}{l}(16) \\
153 / 94(131) \\
40 / 16(27) \\
-9.2 \\
5.3 \\
81 \\
114 \\
1,139 \\
235 \\
91\end{array}$ & $\begin{array}{l}(17) \\
194 / 100(12) \\
40 / 20(26) \\
(7) \\
9.9 \\
5.7 \\
100 \\
99 \\
994 \\
210 \\
72\end{array}$ \\
\hline
\end{tabular}

Values in parentheses indicate mean of systolic and diastolic pressure. 
TABLE \|

Clinical Characteristics in 55 Reported Cases

\begin{tabular}{|c|c|c|c|c|c|}
\hline & $\begin{array}{l}\text { Age (yr) } \\
\text { (mean \& range) }\end{array}$ & Sex & $\begin{array}{l}\text { History of } \\
\text { Syncope }\end{array}$ & $\begin{array}{c}\text { History of } \\
\text { TIA or } \\
\text { Stroke }^{\dagger}\end{array}$ & Cardiomegaly ${ }^{\dagger}$ \\
\hline $\begin{array}{l}\text { Group I ( } n=18)^{1,3-19} \\
\quad \text { (PAS in patients with long-standing cardiac disease) }\end{array}$ & $\begin{array}{c}57 \\
(25-78)\end{array}$ & $9 \mathrm{M} ; 9 \mathrm{~F}$ & $3 / 15$ & $0 / 15$ & $15 / 15$ \\
\hline $\begin{array}{l}\text { Group II ( } n=12)^{2,20-26} \\
\quad \text { (PAS in patients with neuromuscular disorders) }\end{array}$ & $\begin{array}{c}31 \\
(15-46)\end{array}$ & $9 \mathrm{M}, 3 \mathrm{~F}$ & $1 / 12$ & $4 / 12$ & $5 / 6$ \\
\hline $\begin{array}{l}\text { Group III ( } n=24)^{8,14,27-40} \\
\text { (PAS in apparently healthy persons) }\end{array}$ & $\begin{array}{l}36 * \\
(21-61)\end{array}$ & $12 \mathrm{M}, 6 \mathrm{~F}$ & $12 / 21$ & $4 / 21$ & $16 / 18$ \\
\hline
\end{tabular}

* Age and sex data available in only 18 patients. ${ }^{\dagger}$ Data not available in alt reports; the denominator indicates the number of patients for which information is available.

PAS = permanent atrial standstill; TIA - transitory cerebral ischemic attack.

opsy of the right atrium showed diffuse atrial fibrosis.

All available pathologic data from patients with permanent atrial standstill have confirmed severe and widespread atrial fibrosis and degeneration. ${ }^{1,6,9-13,27-30}$ The arrhythmia appears to be a nonspecific result of advanced structural changes.

Patients with neuromuscular disease: The second clinical group in which permanent atrial standstill occurs is in association with various neuromuscular diseases. Originally described in patients with fascioscapulohumeral muscular dystrophy, ${ }^{2,20-21}$ atrial standstill has now been recognized with Charcot-Marie muscular dystrophy, ${ }^{22}$ an X-linked humeroperoneal neuromuscular disease, ${ }^{23}$ Emery-Dreifuss muscular dystrophy, ${ }^{24}$ and limb-girdle muscular dystrophy. ${ }^{25,26}$ Our patient is the first with limb-girdle muscular dystrophy in whom the onset of permanent atrial standstill preceded the clinical muscular disease. The finding of permanent atrial standstill in this group of patients is not surprising because Perloff et al. ${ }^{12}$ emphasized the frequency of myocardial disease as a feature of the muscular dystrophies; they described the spectrum of cardiac dysfunction ranging from asymptomatic supraventricular arrhythmias to severe failure and death. Autopsy findings showed diffuse myocardial fibrosis and scarring.

Patients with syncope, vertigo or stroke: The third group of patients in whom permanent atrial standstill occurs, generally in the 3rd to 5th decade, are without known cardiac or neuromuscular disease. The diagnosis is made when the patient experiences vertigo, ${ }^{27,31,32}$ syncope $\mathrm{e}^{14,30,33-35}$ or stroke $\mathrm{e}^{14,36,37}$ or during a routine physical examination. ${ }^{38}$ These patients deny previous cardiac symptoms except for awareness of their slow heart rate. If the observations in other patient groups hold true, one would expect these apparently healthy persons to have extensive myocardial disease which is otherwise silent. In one series, biopsy of the right atrium or ventricle, or both, showed diffuse degeneration, an increase in interstitial tissues and thickening of the right atrial endocardium. ${ }^{29}$

Familial occurrence: As in our case, the familial occurrence of permanent atrial standstill has been noted with muscular dystrophy ${ }^{22,23}$ as well as in apparently healthy pcrsons. $7,12,35,36,39$ Further longitudinal family studies as well as pathologic study are needed to clarify the disease process in these persons.

Diagnosis: The diagnosis of permanent atrial standstill is important because the morbidity is high. It should be suspected in any patient with absent $P$ waves in the surface electrocardiogram and a regular $\mathrm{R}-\mathrm{R}$ interval. The echocardiogram provides another noninvasive means to demonstrate atrial standstill. Under normal conditions the mitral valve is ballooned out by the force of the atrial contraction at the end of diastole. In atrial standstill, as in atrial fibrillation, the atrial kick is not present on mitral valve recordings (Fig. 2). If the noninvasive studies are consistent with permanent atrial standstill, invasive studies are needed to confirm the diagnosis.

Treatment of patients with permanent atrial standstill should be directed toward the major complications of this condition which consist of syncope, stroke, congestive heart failure and sudden death. Permanent ventricular pacing and long-term anticoagulation appear to be the most promising treatments for these patients.

\section{References}

1. Chavez I, Brumlik J, Pallares DS. Sobre un caso extroardinario de paralisis auricular permanente con degeneracion del nudulo de Keith Y Flack. Arch Inst Cardiol Mex 1946;16:159-81.

2. Baldwin BJ, Talley RC, Johnson C, Nutter DO. Permanent paralysis of the atrium in a patient with facioscapulohumeral muscular dystrophy. Am J Cardiol 1973;31:649-53.
3. Khan AH, Haider R, Boughner DR, Oakley CM, Goodwin JF. Sinus rhythm with absent $P$ waves in advanced rheumatic heart disease. Am J Cardiol 1973;32:93-7.

4. Froment R, Touboul P, Gallavardin L, Porte J, Dufour R. Signification de la réduction spontanée de fibrillations auriculaires anciennes. Arch Mal Coour 1976;69:315-20. 
5. Friedman HS, Gomes JA, Tardio A, Levites R, Haft J. Appearance of atrial hythm with absent $P$ wave in longstanding atrial fibrillation. Chest 1974;66:172-5.

6. Brechenmacher C, Coumel P, Slama R. Paralysie auriculaire apparente et troubles de la conduction auriculo-ventriculaire. Arch Mal Coeur 1975;68:575-80.

7. Jouve A, Amichot JL, Prudhomme F. Paralysie auriculaire. Marseille Med 1969;106:431-6.

8. Slama R, Coumel P, Perrault MA, Bouvrain Y. Dilation idiopathique de l'oreillette driote avec troubles du rythme auriculaire et paralysie auriculaire apparente. Arch Mal Coeur 1973;66:35-47.

9. Ross AM, Proper MC, Aronson AL. Sinoventricular conduction in atrial standstill. J Electrocardiol 1976;9:161-4.

10. Effendy F, Bolognesi R, Bianchi G, Visioli O. Alternation of partial and total atrial standstill. J Electrocardiol 1979;12:121-7.

11. Rosen K, Rahimtoola S, Gunnar RM, Lev M. Transient and persistent atrial standstill with His bundle lesions. Circulation 1971 44:220-36.

12. Raynaud $\mathbf{R}$, Jobard P, Brochler M, Fauchler JP, Benatre A, Raynaud P. Paralysie auriculaire chronique et oriellette papyracée. Ann Cardiol Angeiol 1968;17:117-24.

13. Patton RD, Damato AN, Berkowitz WD, Lau SH, Stein E. The electrically silent right atrium. J Electrocardiol 1970;3:239-43.

14. Kurokawa A, Kurita A, Kasai G, Kimura E. Persistent atrial standstill, report of three cases. J Electrocardiol 1975;8:35762 .

15. Pop T, Fleischmann D, Rupp M, Hagemann K, Effert S. Vorhofstillstand. Klin Wochenschr 1975;53:171-6.

16. Nasi C, Legnani L. Paralisi atriale permanente con molteplici centri idioventricolari di sostituzione. Cardiol Prat 1966;17:472 -80.

17. Critelli G, Chiarlello M, Maione S, Perticone F, Ferro G, Condorell M. Paralysie auriculaire permanente. Arch Mal Coeur 1978;71: 831-5.

18. Lekieffre J, Asseman P, Thery $\mathbf{C}$, et al. La paralysie auriculaire permanente: ses rapports avec la maladie de l'oreillette. Ann Cardiol Angeiol 1979;28:235-48.

19. Hover AR, Koppes GM. Atrial standstill and complete heart block in systemic lupus erythematosis. Chest 1979;76:230-1.

20. Bloomfield DA, Sinclair-Smith BC. Persistent atrial standstil. Am J Med 1965;39:335-9.

21. Caponnetto S, Pastorini C, Tirelli G. Persistent atrial standstill in a patient affected with facioscapulohumeral dystrophy. Cardiologia 1968;53:341-50.

22. Bensaid J, Cligenkrantz J, Fernandez F, et al. Paralysie auriculaire permanents familiale en rapport probable avec une maladie génetique du type Charcot-Marie. Arch Mal Coeur 1971;65:935-53.

23. Waters DD, Nutter DO, Hopkins LC, Dorney ER. Cardiac features of an unusual $X$-linked humeroperoneal neuromuscular disease. N Engl J Med 1975;293:1017-22.

24. Rowland $L$, Fetell $M$, Olarte $M$, Hays $A$, Singh $N$, Wanat $F$. Emery-Dreifuss muscular dystrophy. Ann Neurol 1979;5:111-7.

25. Antonio J, Diniz MC, Miranda D. Persistent atrial standstill with limb girdle muscular dystrophy. Cardiology 1978;63:39-46.

26. Rappelli A, Gagna C, Fabris F. Standstill atriale permanente in un paziente affetto da distrofia muscolare progressiva e da diabete mellito. Minerva Cardioangiol 1969;17:63-8.

27. Allensworth DS, RIce GJ, Lowe GW. Persistent atrial standstill in a family with myocardial disease. Am J Med 1969;47:775-84.

28. Harrison WH, Derrick JR. Atrial standstill. Angiology 1969;20; 610-7.

29. Mizuno Y, Yasui S, Sotabata I, et al. Electrophysiologic and histological studies on patients with atrial standstill. Jpn J Med 1974; 13:35-6.

30. Tanaka $\mathbf{H}$, Atsuchi $\mathbf{Y}$, Tanaka $\mathbf{N}$, et al. Persistent atrial standstill due to atrial inexcitability - an electrophysiological and histological study. Jpn Heart J 1975;16:639-53.

31. Jouve A, Delaage M, Toressani J, Nicolai P, Heulllet G, Pinas E. La paralysie auriculaire (auricular standstill). A propos de 4 observations avec dérivations endocavitaires or oesophagiennes. Arch Mal Coeur 1967;60:865-83.

32. Wakasugi S, Okamoto K, Fudemoto $Y$, Toyama S. Flutter and fibrillation-like phenomenon of His bundle observed in a patient with persistent atrial standstill. J Electrocardiol 1979;12:109-16.

33. Wada M, Takda C, Mise J. A case report of atrial standstill. Jpn Circ J 1966;30:543-53.

34. Benchimol C, Schlesinger P, Ginefra P, Barbosa S, Saad E, Benchimol A. Persistent atrial standstill. Acta Cardiol (Brux) 1975;30:313-22.

35. Kanemoto $\mathbf{N}$, Uchiyama $F$, Sasamoto $H$, et al. A case of persistent atrial standstill. Eur J Cardiol 1979;9:175-80.

36. Coombs DT, Bellaci HF, Shively HH, Gregoratos G. Persistent atrial standstill. Am J Med 1974;56:231-6.

37. Harris CL, Baldwin BJ. Permanent atrial paralysis. J Electrocardiol 1976;9:81-4

38. Derrida J, Forman J, Fouchard J, Degeorges M. La paralysie auriculaire chronique. Coeur Med Interne 1971:10:467-77.

39. Nagle RE, Smith B, Williams DO. Familial atrial cardiomyopathy with heart block. (abstr). Br Heart J 1972;34:205

40. Messinger WJ, Mirkinson AM. Permanent atrial standstill. Arch Intern Med 1969;124:211-4.

41. Ruff P, Leier CV, Schaal SF. Temporary atrial standstill. Am Heart $\mathrm{J}$ 1979;98(4):413-20.

42. Perloff JK, DeLeon AC, O'Doherty D. The cardiomyopathy of progressive muscular dystrophy. Circulation 1966;33:625-48. 